\title{
Ionotropic Glutamate Receptor GluR1 in the Visual Cortex of Hamster: Distribution and Co-Localization with Calcium-Binding Proteins and GABA
}

\author{
Eun-Ah Ye', Tae-Jin Kim ${ }^{1}$, Jae-Sik Choi ${ }^{1}$, Mi-Joo Jin ${ }^{1}$, Young-Ki Jeon ${ }^{1,2}$, Moon-Sook Kim ${ }^{1}$ \\ and Chang-Jin Jeon ${ }^{1}$
}

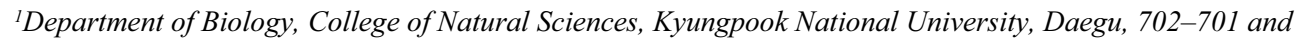

${ }^{2}$ Department of Ophthalmic Optics, Kundong University, Andong, 760-833, Korea

Received December 27, 2005; accepted February 20, 2006

\begin{abstract}
The subunit composition of the AMPA receptor is critical to its function. AMPA receptors that display very low calcium permeability include the GluR2 subunit, while AMPA receptors that contain other subunits, such as GluR1, display high calcium permeability. We have studied the distribution and morphology of neurons containing GluR1 in the hamster visual cortex with antibody immunocytochemistry. We compared this labeling to that for calbindin D28K, parvalbumin, and GABA. Anti-GluR1-immunoreactive (IR) neurons were located in all layers. The highest density of GluR1-IR neurons was found in layers II/III. The labeled neurons were non-pyramidal neurons, but were varied in morphology. The majority of the labeled neurons were round or oval cells. However, stellate, vertical fusiform, pyriform, and horizontal neurons were also labeled with the anti-GluR1 antibody. Two-color immunofluorescence revealed that many of the GluR1-IR neurons in the hamster visual cortex were double-labeled with either calbindin D28K (31.50\%), or parvalbumin $(22.91 \%)$, or GABA $(63.89 \%)$. These results indicate that neurons in the hamster visual cortex express GluR1 differently according to different layers and selective cell types, and that many of the GluR1-IR neurons are limited to neurons that express calbindin D28K, parvalbumin, or GABA. The present study elucidates the neurochemical structure of GluR1, a useful clue in understanding the differential vulnerability of GluR1-containing neurons with regard to calcium-dependent excitotoxic mechanisms.
\end{abstract}

Key words: calbindin D28K, parvalbumin, GABA, GluR1, localization

\section{Introduction}

Glutamate is a neurotransmitter responsible for mediating the vast majority of excitatory synaptic transmission in the vertebrate central nervous system. There are three types of ionotropic glutamate receptors that mediate their actions, which are divided into three groups by their selective agonist: AMPA (alpa-amino-3-hydroxy-5-methyl-4-isoxazole proprionate), NMDA (N-methyl-D-aspartate), and kainite receptors. Each of the receptors is structurally, pharmacologically, and physiologically distinct [7, 42, 53]. AMPA

Correspondence to: Chang-Jin Jeon, Neuroscience Lab., Department of Biology, College of Natural Sciences, Kyungpook National University, 1370 Sankyuk-dong, Daegu, 702-701 S. Korea.

E-mail: cjjeon@knu.ac.kr receptors participate in the synaptic plasticity thought to underlie memory and learning, as well as in the formation of neural network during development. AMPA receptors are formed from the assembly of several protein subunits, named GluR1-4 (or GluRA-D). Native AMPA receptors are most likely tetramers generated by the assembly of one or more of these subunits, yielding homomeric or heteromeric receptors [22, 38, 44, 51, 53].

Calcium is known to be an important moderator of a number of vital physiological processes, including neuronal excitability, axonal transport, and neurotransmitter release. The AMPA receptors not only allow the passage of sodium and potassium, but also allow the passage of calcium in some cases. AMPA receptors that display very low calcium permeability include the GluR2 subunit, while AMPA receptors that contain other subunits, such as GluR1, display 
high calcium permeability $[6,41,52,53]$. Calcium-binding proteins are thought to play a role as intracellular calcium buffers [1]. Among the many calcium-binding proteins, three EF calcium-binding proteins, calbindin D28K, calretinin and parvalbumin, have been studied widely in the central nervous system. GluR1-immunoreactive (IR) neurons in the visual cortex of the monkey [3] and rat [15] have been described. Calcium-binding proteins are localized in the visual cortex of several mammals including human $[2,11,20$, 33-36], monkey [2, 8, 12, 14, 19, 20, 40, 59, 60], dolphin $[11,12]$, cat $[9,21,24,54]$, rabbit [45], flying fox [23], ferret $[10]$, rat $[5,13,37]$, mouse [46], and hamster [31].

Recently, GluR2/3-IR neurons in the hamster visual cortex have been described from our lab [49]. However, localization of GluR1 has not been accomplished and information on the localization of calcium permeable AMPA receptor subunit GluR1 is critical for the understanding of visual activity in the hamster visual cortex, glutamate excitocytotoxicity, and epileptic and ischemic cell damage mediated by AMPA receptors. Thus, the present study was undertaken to investigate the specific laminar distribution and the specific cell type of GluR1-containing cells. Calcium permeability through AMPA receptors strongly depends upon the GluR subunit. Calcium-binding proteins are thought to play a major role in buffering the intracellular calcium level [1]. Recent study in our lab has shown that none of the GluR2/3-IR neurons contained any calcium-binding proteins in the hamster visual cortex. Thus, the second goal of the current study was to investigate whether calcium permeable AMPA receptor subunit GluR1 is specifically localized in subpopulations of calcium-binding protein-containing neurons. Previous studies have shown that the majority of calcium-binding protein-containing neurons in the visual cortex are interneurons containing GABA, which is a major inhibitory neurotransmitter in the vertebrate central nervous system $[9,13,30,40]$. Thus, our final goal was to investigate whether GluR1 is co-localized in GABAergic interneurons. As vision is more important than any other sense in most mammals, the present goals are essential requirements in elaborating the quality and quantity of visual information processing in the visual cortex. The present study also enables us not only to detect the neurochemical structure of GluR1, but also to perceive the animal variety.

\section{Materials and Methods}

\section{Perfusion and tissue processing}

Ten adult hamsters (8-10 weeks old, 20-30 g) were used in these experiments. The guidelines of the National Institute of Health regarding the use and care of animals were followed for all experimental procedures. All efforts were made to minimize animal suffering as well as the number of animals used. All animals were anesthetized deeply with a mixture of ketamine hydrochloride $(30-40 \mathrm{mg} / \mathrm{kg}$ ) and xylazine (3-6 mg/kg) before perfusion. They were perfused transcardially with $4 \%$ paraformaldehyde and $0.3-$ $0.5 \%$ glutaraldehyde in $0.1 \mathrm{M}$ sodium phosphate buffer $(\mathrm{pH}$
7.4) with $0.002 \%$ calcium chloride. Following a pre-rinse with approximately $30 \mathrm{ml}$ of phosphate-buffered saline (PBS, $\mathrm{pH}=7.2$ ) over a period of 1-4 min, each hamster was perfused with $30-50 \mathrm{ml}$ of fixative for 5-10 min via a syringe needle inserted through the left ventricle and aorta. The head was then removed and placed in the fixative for $2-3 \mathrm{hr}$. The brain was removed from the skull, stored for $2-3 \mathrm{hr}$ in the same fixative, and left overnight in $0.1 \mathrm{M}$ phosphate buffer $(\mathrm{pH}=7.4)$ containing $8 \%$ sucrose and $0.002 \% \mathrm{CaCl}_{2}$. The visual cortex was removed, mounted onto a chuck, and cut coronally into $50 \mu \mathrm{m}$ thick sections with a vibratome. For every three or four sections, two or three sections were used for immunocytochemistry and one was used for thionin. The thionin stained sections were used to identify the cortical layers.

\section{HRP immunocytochemistry}

A polyclonal antibody against GluR1 (AB 1504) and a monoclonal antibody against GABA were obtained commercially from Chemicon (USA). Monoclonal antibodies against calbindin D28K and parvalbumin were obtained from Sigma Chemical (USA). These antibodies have been widely used for the localization of GluR1, GABA, and calcium-binding proteins in the central nervous system. The tissue was processed free floating in small vials. For immunocytochemistry, sections were incubated in $1 \%$ sodium borohydride $\left(\mathrm{NaBH}_{4}\right)$ for $30 \mathrm{~min}$. Sections were rinsed $3 \times 10 \mathrm{~min}$ in $0.1 \mathrm{M}$ phosphate buffer and incubated in $0.1 \mathrm{M}$ phosphate buffer with $4 \%$ normal goat serum for $2 \mathrm{hr}$ with $0.5 \%$ Triton X-100. They were then incubated in the primary antiserum, that had been diluted 1:200-1:250, in $0.1 \mathrm{M}$ phosphate buffer with $4 \%$ normal serum for $48 \mathrm{hr}$ in the presence of $0.5 \%$ Triton X-100. Following a further $3 \times 10$ min rinse in $0.1 \mathrm{M}$ phosphate buffer, the sections were incubated in a 1:200 dilution of biotinylated secondary IgG in $0.1 \mathrm{M}$ phosphate buffer with $4 \%$ normal serum for $2 \mathrm{hr}$ in the presence of $0.5 \%$ Triton X-100, then rinsed $3 \times 10 \mathrm{~min}$ in $0.1 \mathrm{M}$ phosphate buffer and incubated in a 1:50 dilution of avidin-biotinylated horseradish peroxidase (Vector Lab., USA) in $0.25 \mathrm{M}$ Tris for $2 \mathrm{hr}$. The sections were rinsed as before, and staining was visualized by reaction with 3,3'diaminobenzidine tetrahydrochloride (DAB) and hydrogen peroxide in $0.25 \mathrm{M}$ Tris for $3-10 \mathrm{~min}$ using a DAB reagent set (Kirkegaard \& Perry, USA). All sections were rinsed in $0.1 \mathrm{M}$ phosphate buffer before mounting. As a control, some sections were incubated in the same solution without the addition of the primary antibody. In addition, preabsorption of anti-GluR1 antibody with the corresponding synthetic peptide (Chemicon, AG 360, $10 \mu \mathrm{g}$ of peptide/ml, $12 \mathrm{hr}$ incubation at room temperature) was performed prior to tissue incubation. These control tissues showed no GluR1 immunoreactivity (Fig. 1C and D). The stained tissues were finally mounted on Superfrost Plus slides (Fisher, USA) and dried overnight in an oven set at $37^{\circ} \mathrm{C}$, dehydrated through alcohol, cleared with xylene, and covered with coverslips in mounting medium (Permount; Fisher). The tissues were examined with a Zeiss Axioplan microscope 

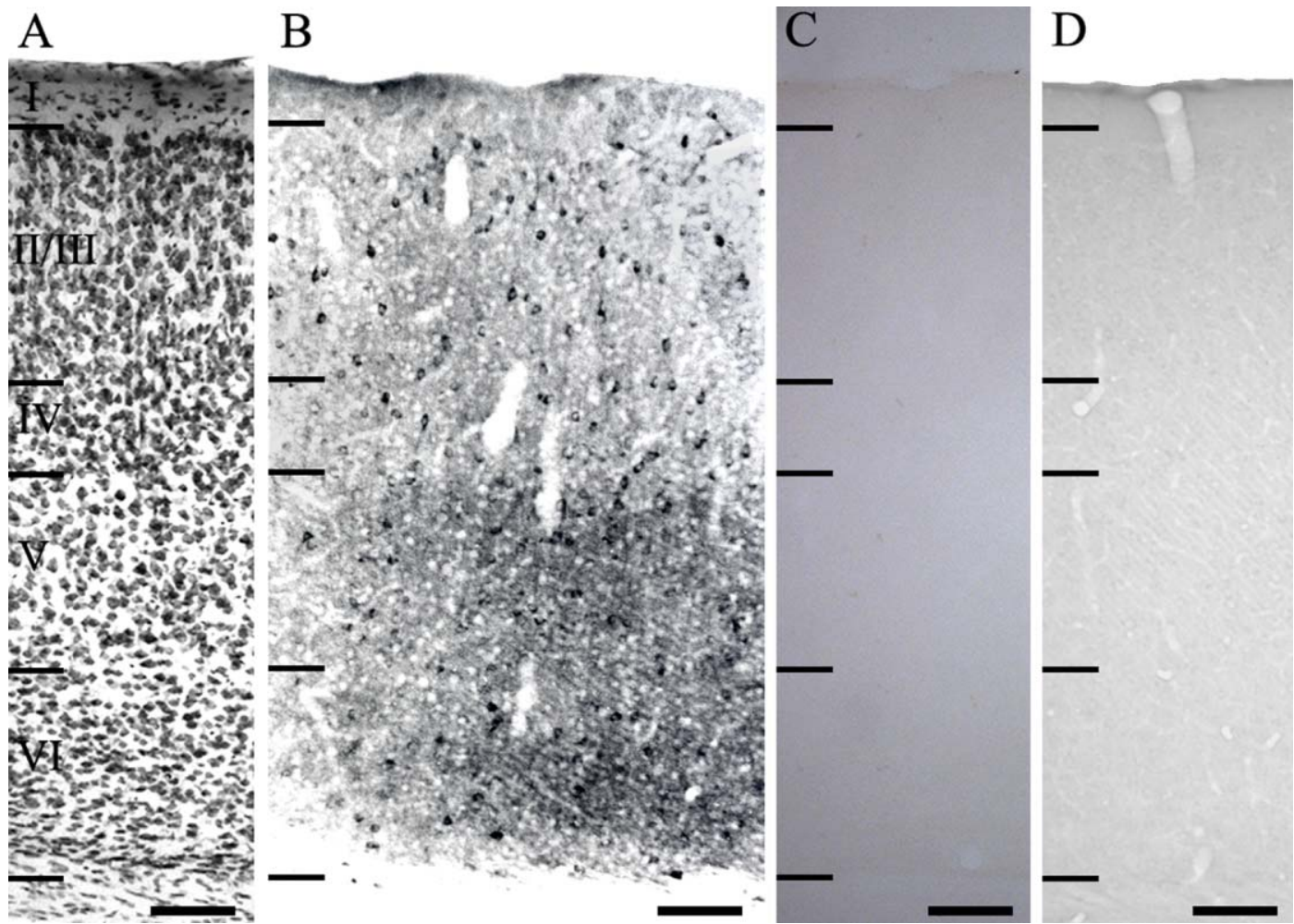

Fig. 1. Low power photomicrographs of the distribution of GluR1-IR neurons in the hamster visual cortex. (A) Thionin-stained section shows the cortical lamination. (B) Anti-GluR1-IR neurons. (C, D) Control sections used to show the specificity of GluR1 antibody. In C, section was incubated without the addition of the primary antibody. In $\mathbf{D}$, the GluR1 antibody was preabsorbed with antigen prior to tissue incubation. I-VI: cortical layers. Bar $=100 \mu \mathrm{m}$.

using conventional or differential interference contrast (DIC) optics.

\section{Fluorescence immunocytochemistry}

To double-label sections for GluR1 and calbindin D28K, parvalbumin, or GABA, sections were incubated in the primary antiserum as described above. The primary antiserum was diluted at either 1:250 (GluR1 and calbindin D28K), or 1:200 (parvalbumin and GABA). The secondary antibodies were Cy5 conjugated anti-rabbit IgG (Jackson ImmunoResearch Lab.) for GluR1 and fluorescein (FITC) conjugated anti-mouse IgG (Vector Lab., USA) for calbindin D28K, parvalbumin, or GABA. Labeled sections were preserved under coverslips in Vectashield mounting medium (Vector Lab., USA), and images were obtained using a Bio-Rad MRC 1024 laser scanning confocal microscope.

\section{Quantitative analysis}

The GluR1-containing neurons were plotted with the aid of a Zeiss drawing tube attached to a Zeiss Axioplan microscope with a $20 \times$ objective. We took samples from six different sections, each $1000 \mu \mathrm{m}$ in width, from each of two animals. The number of labeled neurons was expressed as a percentage of the total population of labeled neurons. Double-labeled neurons were counted from six different sections, each $550 \mu \mathrm{m}$ in width, from each of two animals across all layers. Double-labeled images were obtained using a Bio-Rad MRC 1024 laser scanning confocal microscope using a $20 \times$ objective. The morphological types of GluR1-IR cells were analyzed on DAB-reacted sections. All analyses were done with a $40 \times$ Zeiss Plan-Apochromat objective. We took samples from six different sections, each $1000 \mu \mathrm{m}$ in width, from each of two animals across all layers. To obtain the best images, we analyzed cells under DIC optics. Only cell profiles containing a nucleus and at least a faintly visible nucleolus were included in this analysis. Since the goal of the present study was to obtain an estimate of each morphological cell type, no attempt was made to assess the total number of cells of each neuronal subpopulation.

\section{Results}

\section{Distribution of GluR1 immunoreactivity}

Figure 1B shows GluR1 immunoreactivity in the hamster visual cortex while Figure 1A shows a thionin-stained section for cortical lamination. GluR1 was present in a large subset of neurons within the adult hamster visual cortex with the highest density in layer II/III. In layer I of the visual cortex, GluR1-IR neurons were rarely encountered. A quantitative histogram of cell distribution revealed the density of the GluR1-IR neurons in each layer (Fig. 2). The frequency of 
Ye et al.

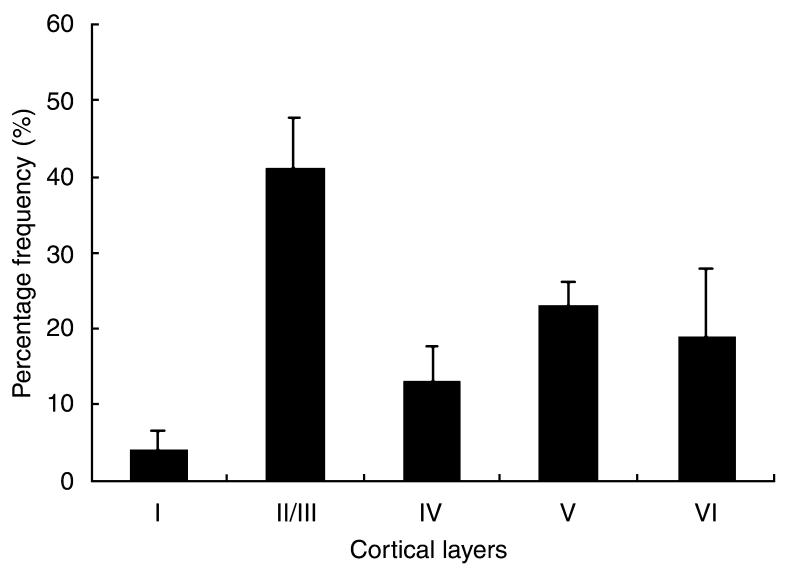

Fig. 2. Histogram of the distribution of neurons labeled by antiGluR1 antibody in the hamster visual cortex. Anti-GluR1-IR neurons were predominantly located in layers II/III, V and VI. Error bars: SD.

labeled neurons varied in each layer. Thus, 3.98\% (S.D. 2.72) (total 63 cells from 6 sections) of labeled neurons were found in layer I, $41.01 \%$ (S.D. 6.84) (total 640 cells from 6 sections) in layer II/III, 13.18\% (S.D. 4.30) (total 202 cells from 6 sections) in layer IV, 22.91\% (S.D. 3.39) (total 354 cells from 6 sections) in layer $\mathrm{V}$, and 18.94\% (S.D. 8.96) (total 295 cells from 6 sections) in layer VI.

\section{Morphology of anti-GluRI-IR neurons}

In the hamster visual cortex, the majority of the GluR1IR cells consisted of round or oval cells. Figures $3 \mathrm{~A}$ and $3 \mathrm{~B}$ (arrow) show representative multipolar round or oval cells. The round or oval cells were located in all layers. Figure 3B (arrowhead) and 3D show multipolar stellate neurons. Stellate cells had polygonally-shaped cell bodies with numerous dendrites coursing in all directions. The stellate cells were located in all layers except in layer I. Vertical fusiform cells (Fig. 3C and asterisk in 3B) with a thick, proximal dendritic stump directed towards the pial surface were also found. Vertical fusiform cells were predominantly located in layer II/III. Fig. 3E shows a pyriform neuron. Pyriform neurons had a small, pear-shaped cell body with a thick proximal dendrite directed toward the pial surface. The ascending process had many small branches, which formed a dendritic bouquet. The pyriform cells were predominantly located in layer II/III. Horizontal cells (Fig. 3F), with horizontally-oriented small, fusiform cell bodies and horizontally-oriented processes, also contained GluR1. The horizontal cells were predominantly located in layer I. Quantitatively, 73.54\% (S.D. 6.71) of anti-GluR1 labeled neurons were round or oval, $15.55 \%$ (S.D. 7.21) were vertical fusiform, 7.52\% (S.D. 1.95) were stellate, $2.10 \%$ (S.D. 0.88 ) were pyriform, and $1.29 \%$ (S.D. 1.02) was horizontal neurons. In the present study, we could not identify any GluR1-IR pyramidal cells.
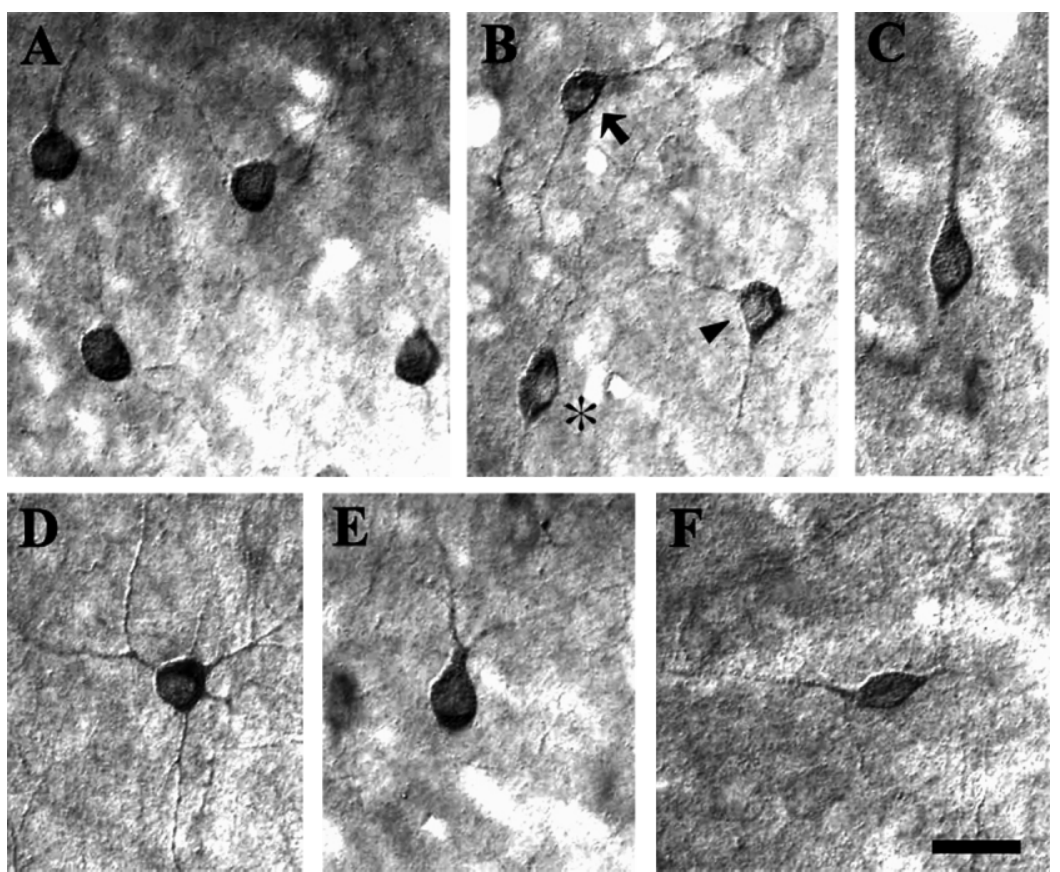

Fig. 3. High power differential interference contrast (DIC) photomicrographs of some GluR1-IR neurons in the hamster visual cortex. (A, B arrow) Multipolar round or oval neurons in cortical layers II/III. The large majority of anti-GluR1-IR neurons were round or oval cells with many dendrites coursing in all directions. (B arrowhead, D) Multipolar stellate neurons. Stellate neurons had polygonally-shaped cell bodies with numerous dendrites coursing in all directions. (B asterisk, C) Vertical fusiform neurons with its longitudinal axis perpendicular to the pial surface. (E) Pyriform neuron with a thick primary dendrite oriented toward the pial surface. This ascending process had many small branches, forming a dendritic bouquet. (F) A horizontal neuron with a horizontal fusiform cell body with horizontally oriented processes. Bar=20 $\mu \mathrm{m}$. 


\section{Co-localization of GluR1 and calbindin D28K or parvalbumin or $\boldsymbol{G A B A}$}

To determine whether the GluR1-IR cells in the hamster visual cortex co-localize with calbindin D28K or parvalbumin or GABA, we labeled GluR1 with Cy5 and calbindin D28K or parvalbumin or GABA with fluorescein. Some cells were clearly labeled by both GluR1 and calbindin D28K or parvalbumin or GABA in the hamster visual cortex. Other cells were labeled by either one of the antibodies, but not by both (Fig. 4). There was no obvious relationship between cell morphology and whether the cell was single or double labeled. To estimate the percentage of doublelabeled cells, we counted the numbers of GluR1 and doublelabeled cells across the layers of the visual cortex in six sections from two animals. Quantitatively, $31.50 \%$ of the GluR1-IR cells were double-labeled with calbindin D28K in the hamster visual cortex, while $22.91 \%$ of the GluR1-IR cells were double-labeled with parvalbumin. Quantitatively, $63.89 \%$ of the GluR1-IR neurons contained GABA (Table 1).

\section{Discussion}

The results indicate that the GluR1-IR neurons were widely distributed in the hamster visual cortex with the highest density in layers II/III and with the lowest density in layer I. Differences in the GluR1 expression patterns were found even among the rodents. In contrast to the hamster visual cortex, more than half of the GluR1-IR neurons are located in layer VI in rat visual cortex [15]. Immunoreactivity for GluR1 is densest in layers IV and VI in the monkey visual cortex [3]. Although the functional significance of the subtle species differences in GluR1 expression is not yet understood, these differences may contribute to the specific physiological properties of GluR1-containing neurons in the visual cortex among different species.

In the present study of the hamster visual cortex, the GluR1-IR cells were non-pyramidal cells. Although the morphology of the GluR1-IR non-pyramidal neurons was diverse, the majority of the neurons were multipolar round or oval cells. Previous studies have shown the morphology

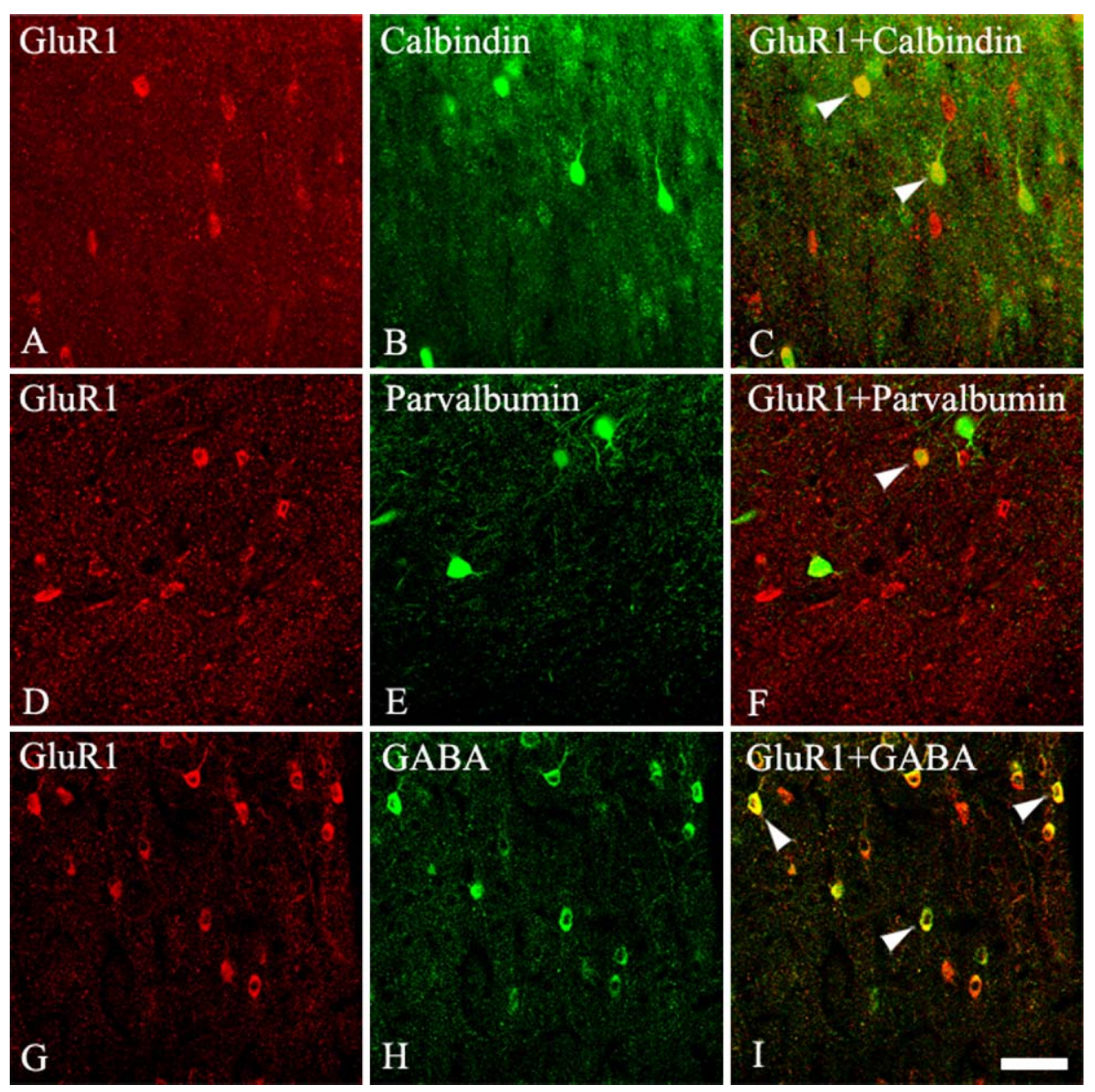

Fig. 4. Fluorescence confocal photomicrographs of hamster visual cortex immunostained for (A, D, G) GluR1 (B) calbindin D28K, (E) parvalbumin, and (H) GABA. (C) Superimposition of images in GluR1 and calbindin D28K. (F) Superimposition of images in GluR1 and parvalbumin. (I) Superimposition of images in GluR1 and GABA. Arrowheads indicate some co-localized neurons. The double-labeled neurons were found in all layers except in layer I. Bar $=50 \mu \mathrm{m}$. 
Table 1. Percentage of GluR1 cells, and double-labeled cells with calcium-binding proteins and GABA in the hamster visual cortex

\begin{tabular}{lccccc}
\hline & Animal No. & No. sections & No. GluR1 & No. double & \% Double (Mean \pm S.D.) \\
\hline \multirow{3}{*}{ Calbindin D28K } & 3 & 3 & 299 & 79 & $26.48 \pm 1.45$ \\
& 7 & 3 & 349 & 121 & $36.52 \pm 16.26$ \\
& Total & 6 & 648 & 200 & $31.50 \pm 11.70$ \\
\hline \multirow{3}{*}{ Parvalbumin } & 3 & 3 & 224 & 43 & $21.52 \pm 15.68$ \\
& 7 & 3 & 302 & 74 & $24.30 \pm 3.29$ \\
& Total & 6 & 526 & 280 & $75.92 \pm 10.24$ \\
\hline \multirow{3}{*}{ GABA } & 3 & 3 & 369 & 182 & $51.97 \pm 18.60$ \\
& 7 & 3 & 707 & 462 & $63.89 \pm 18.75$ \\
\hline
\end{tabular}

of GluR1-IR neurons in a variety of areas of mammalian brain such as the cat visual cortex [16], rat somatosensory cortex [27, 28], rat hippocampus [32], and rat amygdala [39]. The strongly labeled neurons were non-pyramidal cells. In contrast to GluR1, GluR2/3-immunoreactivity was found in pyramidal neurons both in the visual cortex $[16,49]$ and in other cortical areas [39, 43, 55-58]. These previous results along with the present results indicate that subsets of interneurons primarily express GluR1, while subsets of projection neurons primarily express GluR2/3. AMPA receptors are composed of subunits GluR1-4, which are products from separate genes. AMPA receptors that do not contain the GluR2 subunits are permeable to calcium. In accordance with our results, the calcium permeability of AMPA receptors is remarkably higher in non-pyramidal neurons than in pyramidal neurons in the rat neocortex [25].

The large majority of GluR1-IR neurons contained GABA in rat somatic sensory cortex [27]. Our results also showed that about two thirds of GluR1-containing neurons co-expressed GABA. These results indicate that many GluR1-containing neurons in the hamster visual cortex are GABAergic interneurons. On the other hand, approximately one fourth of GluR1-containing neurons co-expressed GABA in the rat visual cortex [15]. However, few GluR1-IR neurons contained GABA in monkey amygdala [17]. The results indicate that there are regional and species differences in GABA expressing GluR1-containing neurons, and emphasize the neurochemical diversity of animal species. Thus, to accomplish the functional neurochemical organization of the central nervous system, diverse animal species must be examined.

Celio [4] has shown that interneurons specifically express the calcium-binding proteins calbindin, calretinin, or parvalbumin in the central nervous system. In our previous study, we have shown that hamster visual cortex also contains many calbindin D28K-, calretinin-, or parvalbuminimmunoreactive neurons [31]. The current study has shown that the expression of many GluR1-IR cells is correlated with the expression of calcium-binding proteins. In accordance with the present results, GluR1-IR was found mainly in non-pyramidal neurons that contain calcium-binding proteins $[26,28,29,32,39]$. In contrast to the present study, we previously have shown that none of the GluR2/3-IR neurons in the hamster visual cortex contained calbindin D28K or calretinin [49]. Calcium-binding proteins work as calcium buffers or they actively work in a calcium-mediated signal transduction. Many studies have suggested that calciumbinding proteins play some roles in neuroprotection $[1,18$, $47,48,50,61]$. The AMPA glutamate receptor that displays higher calcium permeability includes the GluR1 subunit. However, any combination of receptors that included the GluR2 subunit produced receptors were impermeable to calcium $[6,41,52,53]$. Thus, the existence of calcium-binding proteins in GulR1-IR neurons and the non-existence of calcium-binding proteins in GluR2/3-IR neurons in our previous study may indicate that many of the GluR1-IR neurons in the hamster visual cortex are protected from calciumoverflowing excitotoxic injury. These results indicate that many GluR1-containing neurons may have different calcium-dependent pathways from GluR2/3-containing neurons in the hamster visual cortex and the functional diversity of AMPA receptors. Clearly, the results of the present study taken together with those of previous studies suggest that the properties of AMPA glutamate receptors can be quite different not only depending on different combination of the subunits, but also depending on differential expression of calcium-binding proteins in particular neuronal cell types.

In conclusion, the present study demonstrates the organizational patterns of GluR1-containing cells in the hamster visual cortex. The highest density of GluR1-IR neurons was found in layers II/III. The labeled neurons varied in morphology and the majority of the labeled neurons were nonpyramidal multipolar round or oval cells. Two-color immunofluorescence revealed that many of the GluR1-IR neurons in the hamster visual cortex were double-labeled with either calbindin D28K, parvalbumin, or GABA. These results indicate that neurons in the hamster visual cortex express GluR1 differently according to different layers and selective cell types and that many of the GluR1-IR neurons are limited neurons that express calbindin $28 \mathrm{~K}$, parvalbumin or GABA. These data elucidate the neurochemical structure of GluR1 and provide a useful clue in understanding the differential vulnerability of GluR1-containing neurons with regard to calcium-dependent excitotoxic mechanisms. The 
data will also help us to better understand the variety of animals.

\section{Acknowledgments}

We thank Dr. Robert Flaherty, the staff of the Language Institute of Kyungpook National University, for proofreading the paper. This work was supported by a Grant (R12-2003-002-02005-0) from the Basic Research Program of the Ministry of Commerce, Industry and Energy.

\section{References}

1. Baimbridge, K. G., Celio, M. R. and Rogers, J. H. (1992) Calcium-binding proteins in the nervous system. Trends Neurosci. 15; 303-308.

2. Blumcke, I., Hof, P. R., Morrison, J. H. and Celio, M. R. (1990) Distribution of parvalbumin immunoreactivity in the visual cortex of Old World monkeys and humans. J. Comp. Neurol. 301; 417-432.

3. Carder, R. K. (1997) Immunocytochemical characterization of AMPA-selective glutamate receptor subunits: laminar and compartmental distribution in mascaque striate cortex. J. Neurosci. $17 ; 3352-3363$.

4. Celio, M. R. (1990) Calbindin D-28k and parvalbumin in the rat nervous system. Neuroscience $35 ; 375-475$.

5. Cellerino, A., Siciliano, R., Domenici, L. and Maffei, L. (1992) Parvalbumin immunoreactivity: a reliable marker for the effects of monocular deprivation in the rat visual cortex. Neuroscience $51 ; 749-753$.

6. Conti, F. and Weinberg, R. J. (1999) Shaping excitation at glutamatergic synapses. Trends Neurosci. 22; 451-458.

7. Cull-Candy, S. G. (2002) Ionotropic glutamate receptors. In "Glutamate and GABA Receptors and Transporters", ed. by J. Egebjerg, A. Schousboe and P. Krogsgaard-Larsen, Taylor \& Francis, London, pp. 3-40.

8. Defelipe, J., Gonzalez-Albo, M. C., Del Rio, M. R. and Elston, G. N. (1999) Distribution and patterns of connectivity of interneurons containing calbindin, calretinin, and parvalbumin in visual areas of the occipital and temporal lobes of the macaque monkey. J. Comp. Neurol. 412; 515-526.

9. Demeulemeester, H., Arckens, L., Vandesande, F., Orban, G. A., Heizmann, C. W. and Pochet, R. (1991) Calcium binding proteins and neuropeptides as molecular markers of GABAergic interneurons in the cat visual cortex. Exp. Brain Res. 84; 538-544.

10. Gao, W. J., Wormington, A. B., Newman, D. E. and Pallas, S. L. (2000) Development of inhibitory circuitry in visual and auditory cortex of postnatal ferrets: immunocytochemical localization of calbindin- and parvalbumin-containing neurons. J. Comp. Neurol. $422 ; 140-157$.

11. Glezer, I. I., Hof, P. R. and Morgane, P. J. (1992) Calretininimmunoreactive neurons in the primary visual cortex of dolphin and human brains. Brain Res. 595; 181-188.

12. Glezer, I. I., Hof, P. R. and Morgane, P. J. (1998) Comparative analysis of calcium binding protein immunoreactive neuronal populations in the auditory and visual systems of the bottlenose dolphin (Tursiops truncatus) and the macaque monkey (Macaca fascicularis). J. Chem. Neuroanat. 15; 203-237.

13. Gonchar, Y. and Burkhalter, A. (1997) Three distinct families of GABAergic neurons in rat visual cortex. Cereb. Cortex. 7; 347358.

14. Goodchild, A. K. and Martin, P. R. (1998) The distribution of calcium-binding proteins in the lateral geniculate nucleus and visual cortex of a New World monkey, the marmoset, Callithrix jacchus. Vis. Neurosci. 15; 625-642.

15. Gutierrez-Ibarluzea, I., Mendizabal-Zubiaga, J. L., Reblet, C. and Bueno-Lopez, J. L. (1997) GABAergic neurons with AMPA GluR1 and GluR2/3 immunoreactivity in the rat striate cortex. Neuroreport 8; 2495-2499.

16. Gutierrez-Igarza, K., Fogarty, D. J., Perez-Cerda, F., DonateOliver, F., Albus, K. and Matute, C. (1996) Localization of AMPA-selective glutamate receptor subunits in the adult cat visual cortex. Vis. Neurosci. 13; 61-72.

17. He, Y., Ong, W. Y. and Leong, S. K. (1996) Localisation of ionotropic glutamate receptor subunits, and gamma-aminobutyric acid (GABA) in the monkey amygdala - a double immunolabelling and electron microscopic study. J. Hirnforsch. 37; 479-503.

18. Heizmann, C. W. and Braun, K. (1995) Calcium Regulation by Calcium-binding Proteins in Neurodegenerative Disorders, Springer-Verlag, New York.

19. Hendrickson, A. E., Van Brederode, J. F., Mulligan, K. A. and Celio, M. R. (1991) Development of the calcium-binding protein parvalbumin and calbindin in monkey striate cortex. J. Comp. Neurol. 307; 626-646.

20. Hendry, S. H. and Carder, R. K. (1993) Neurochemical compartmentation of monkey and human visual cortex: similarities and variations in calbindin immunoreactivity across species. Vis. Neurosci. 10; 1109-1120.

21. Hogan, D. and Berman, N. E. (1994) The development of parvalbumin and calbindin D28k immunoreactive interneurons in kitten visual cortical areas. Brain Res. Dev. Brain Res. 77; 1-21.

22. Hollmann, M. and Heinemann, S. (1994) Cloned glutamate receptors. Annu. Rev. Neurosci. 17; 31-108.

23. Ichida, J. M., Rosa, M. G. and Casagrande, V. A. (2000) Does the visual system of the flying fox resemble that of primates? The distribution of calcium-binding proteins in the primary visual pathway of Pteropus poliocephalus. J. Comp. Neurol. 417; 73-87.

24. Jeon, C. J. and Park, H. J. (1997) Immunocytochemical localization of calcium-binding protein calretinin containing neurons in cat visual cortex. Mol. Cells 7; 721-725.

25. Jonas, P., Racca, C., Sakmann, B., Seeburg, P. H. and Monyer, H. (1994) Differences in Ca2+ permeability of AMPA-type glutamate receptor channels in neocortical neurons caused by differential GluR-B subunit expression. Neuron 12; 1281-1289.

26. Kerr, R. C., Maxwell, D. J. and Todd, A. J. (1998) GluR1 and GluR2/3 subunits of the AMPA-type glutamate receptor are associated with particular types of neuron in laminae I-III of the spinal dorsal horn of the rat. Eur. J. Neurosci. 10; 324-333.

27. Kharazia, V. N., Wenthold, R. J. and Weinberg, R. J. (1996) GluR1-immunopositive interneurons in rat neocortex. J. Сотр. Neurol. 368; 399-412.

28. Kondo, M., Sumino, R. and Okado, H. (1997) Combinations of AMPA receptor subunit expression in individual cortical neurons correlate with expression of specific calcium-binding proteins. J. Neurosci. 17; 1570-1581.

29. Kwok, K. H., Tse, Y. C., Wong, R. N. and Yung, K. K. (1997) Cellular localization of GluR1, GluR2/3 and GluR4 glutamate receptor subunits in neurons of the rat neostriatum. Brain Res. $778 ; 43-55$.

30. Kwong, W. H., Chan, W. Y., Lee, K. K., Fan, M. and Yew, D. T. (2000) Neurotransmitters, neuropeptides and calcium binding proteins in developing human cerebellum: a review. Histochem. J. 32; 521-534.

31. Lee, J. E., Ahn, C. H., Lee, J. Y., Chung, E. S. and Jeon, C. J. (2004) Nitric oxide synthase and calcium binding proteincontaining neurons in the hamster visual cortex. Mol. Cells 18; 30-39.

32. Leranth, C., Szeidemann, Z., Hsu, M. and Buzsaki, G. (1996) AMPA receptors in the rat and primate hippocampus: a possible absence of GluR2/3 subunits in most interneurons. Neuroscience $70 ; 631-652$. 
33. Letinic, K. and Kostovic, I. (1998) Postnatal development of calcium-binding proteins calbindin and parvalbumin in human visual cortex. Cereb. Cortex 8; 660-669.

34. Leuba, G. and Saini, K. (1996) Calcium-binding proteins immunoreactivity in the human subcortical and cortical visual structures. Vis. Neurosci. 13; 997-1009.

35. Leuba, G. and Saini, K. (1997) Colocalization of parvalbumin, calretinin and calbindin D-28k in human cortical and subcortical visual structures. J. Chem. Neuroanat. 13; 41-52.

36. Leuba, G., Kraftsik, R. and Saini, K. (1998) Quantitative distribution of parvalbumin, calretinin, and calbindin D-28k immunoreactive neurons in the visual cortex of normal and Alzheimer cases. Exp. Neurol. 152; 278-291.

37. Luth, H. J., Blumcke, I., Winkelmann, E. and Celio, M. R. (1993) The calcium-binding protein calretinin is localized in a subset of interneurons in the rat cerebral cortex: a light and electron immunohistochemical study. J. Hirnforsch. 34; 93-103.

38. Madsen, U., Johansen, T. N., Stensbol, T. B. and KrogsgaardLarsen, P. (2002) Pharmacology of AMPA/kainite receptors. In "Glutamate and GABA Receptors and Transporters", ed. by J. Egebjerg, A. Schousboe and P. Krogsgaard-Larsen, Taylor \& Francis, London, pp. 99-118.

39. McDonald, A. J. (1996) Localization of AMPA glutamate receptor subunits in subpopulations of non-pyramidal neurons in the rat basolateral amygdala. Neurosci. Lett. 208; 175-178.

40. Meskenaite, V. (1997) Calretinin-immunoreactive local circuit neurons in area 17 of the cynomolgus monkey, Macaca fascicularis. J. Comp. Neurol. 379; 113-132.

41. Michaelis, E. K. (1998) Molecular biology of glutamate receptors in the central nervous system and their role in excitotoxicity, oxidative stress and aging. Prog. Neurobiol. 54; 369-415.

42. Monaghan, D. T., Bridges, R. J. and Cotman, C. W. (1989) The excitatory amino acid receptors: their classes, pharmacology, and distinct properties in the function of the central nervous system. Annu. Rev. Pharmacol. Toxicol. 29; 365-402.

43. Munoz, A., Woods, T. M. and Jones, E. G. (1999) Laminar and cellular distribution of AMPA, Kainite, and NMDA receptor subunits in monkey sensory-motor cortex. J. Comp. Neurol. 407; $472-490$

44. O’Neill, M. J., Bleakman, D., Zimmerman, D. M. and Nisenbaum, E. S. (2004) AMPA receptor potentiators for the treatment of CNS disorders. Curr. Drug Targets CNS Neurol. Disord. 3; 181-194.

45. Park, H. J., Lee, S. N., Lim, H. R., Kong, J. H. and Jeon, C. J. (2000) Calcium-binding proteins calbindin D28K, calretinin, and parvalbumin immunoreactivity in the rabbit visual cortex. Mol. Cells 10; 206-212.

46. Park, H. J., Kong, J. H., Kang, Y. S., Park, W. M., Jeong, S. A., Park, S. M., Lim, J. K. and Jeon, C. J. (2002) The distribution and morphology of calbindin D28K- and calretinin-immunoreactive neurons in the visual cortex of mouse. Mol. Cells 14; 143-149.

47. Polans, A., Baehr, W. and Palczewski, K. (1996) Turned on by $\mathrm{Ca} 2+$ ! The physiology and pathology of $\mathrm{Ca}(2+)$-binding proteins in the retina. Trends Neurosci. 19; 547-554.

48. Reynolds, G. P., Zhang, Z. J. and Beasley, C. L. (2001) Neuro- chemical correlates of cortical GABAergic deficits in schizophrenia: selective losses of calcium binding protein immunoreactivity. Brain Res. Bull. 55; 579-584.

49. Ryoo, S. R., Ahn, C. H., Lee, J. Y., Kang, Y. S. and Jeon, C. J. (2003) Immunocytochemical localization of neurons containing the AMPA GluR2/3 subunit in the hamster visual cortex. Mol. Cells 16; 211-215.

50. Schafer, B. W. and Heizmann, C. W. (1996) The S100 family of EF-hand calcium binding proteins: functions and pathology. Trends Biochem. Sci. 21; 134-140.

51. Seeburg, P. H. (1993) The TINS/TiPS Lecture. The molecular biology of mammalian glutamate receptor channels. Trends Neurosci. 16; 359-365.

52. Sheng, M. and Kim, M. J. (2002) Postsynaptic signaling and plasticity mechanisms. Science 298; 776-780.

53. Song, I. and Huganir, R. L. (2002) Regulation of AMPA receptors during synaptic plasticity. Trends Neurosci. 25; 578-588.

54. Stichel, C. C., Singer, W., Heizmann, C. W. and Norman, A. W. (1987) Immunohistochemical localization of calcium-binding proteins, parvalbumin and calbindin-D 28k, in the adult and developing visual cortex of cats: a light and electron microscopic study. J. Comp. Neurol. 262; 563-577.

55. Tallaksen-Greene, S. J. and Albin, R. L. (1994) Localization of AMPA-selective excitatory amino acid receptor subunits in identified populations of striatal neurons. Neuroscience 61; 509-519.

56. Vickers, J. C., Huntley, G. W., Edwards, A. M., Moran, T., Rogers, S. W., Heinemann, S. F. and Morrison, J. H. (1993) Quantitative localization of AMPA/Kainate and Kainate glutamate receptor subunit immunoreactivity in neurochemically identified subpopulations of neurons in the prefrontal cortex of the macaque monkey. J. Neurosci. 13; 2982-2992.

57. Vissavajjhala, P., Janssen, W. G., Hu, Y., Gazzaley, A. H., Moran, T., Hof, P. R. and Morrison, J. H. (1996) Synaptic distribution of the AMPA-GluR2 subunit and its colocalization with calcium-binding proteins in rat cerebral cortex: an immunohistochemical study using a GluR2-specific monoclonal antibody. Exp. Neurol. 142; 296-312.

58. Xu, L., Tanigawa, H. and Fujita, I. (2003) Distribution of alphaamino-3-hydroxy-5 methyl-4 isoxazolepropionate-type glutamate receptor subunits (GluR2/3) along the ventral visual pathway in the monkey. J. Comp. Neurol. 456; 396-407.

59. Yan, Y. H., van Brederode, J. F. and Hendrickson, A. E. (1995) Developmental changes in calretinin expression in GABAergic and nonGABAergic neurons in monkey striate cortex. J. Comp. Neurol. 363; 78-92.

60. Yan, Y. H., Van Brederode, J. F. and Hendrickson, A. E. (1995) Transient co-localization of calretinin, parvalbumin, and calbindin-D28K in developing visual cortex of monkey. $J$. Neurocytol. 24; 825-837.

61. Yenari, M. A., Minami, M., Sun, G. H., Meier, T. J., Kunis, D. M., McLaughlin, J. R., Ho, D. Y., Sapolsky, R. M. and Steinberg, G. K. (2001) Calbindin d28k overexpression protects striatal neurons from transient focal cerebral ischemia. Stroke 32; 10281035 . 